\title{
Carbon monoxide measurements onboard the CARIBIC passenger aircraft using UV resonance fluorescence
}

\author{
D. Scharffe ${ }^{1}$, F. Slemr ${ }^{1}$, C. A. M. Brenninkmeijer ${ }^{1}$, and A. Zahn ${ }^{2}$ \\ ${ }^{1}$ Max-Planck-Institut für Chemie (MPI), Air Chemistry Division, Hahn-Meitner-Weg 1, 55128 Mainz, Germany \\ ${ }^{2}$ Institut für Meteorologie und Klimaforschung (IMK), Karlsruhe Institute of Technology (KIT), Weberstrasse 5, \\ 76133 Karlsruhe, Germany
}

Correspondence to: F. Slemr (franz.slemr@mpic.de)

Received: 6 February 2012 - Published in Atmos. Meas. Tech. Discuss.: 4 April 2012

Revised: 15 June 2012 - Accepted: 21 June 2012 - Published: 24 July 2012

\begin{abstract}
Goal of the project CARIBIC (Civil Aircraft for the Regular Investigation of the atmosphere Based on an Instrumented Container) is to carry out regular and detailed observations of atmospheric composition (particles and gases) at cruising altitudes of passenger aircraft, i.e. at $9-12 \mathrm{~km}$. Continuous, fast measurement of $\mathrm{CO}$ is indispensable for the chemical characterization of encountered air masses, for the detection of plumes of polluted air and for studying troposphere-stratosphere transport. $\mathrm{CO}$ is measured by a commercial resonance fluorescence UV instrument modified for the use onboard passenger aircraft. Modifications were necessary to optimize the instrument reliability allowing unattended operation for several days. The instrument has a precision of 1-2 ppbv at an integration time of $1 \mathrm{~s}$. The response time to reach $63.2 \%$ signal strength is $2 \mathrm{~s}$. We describe the modifications of the instrument, the experiences made during its operation since December 2004, the quality control of CO measurements onboard CARIBIC, and suggest a regular service routine that guarantees long-term highquality data.
\end{abstract}

\section{Introduction}

Of the present three projects using passenger aircraft to sample the upper troposphere and lower stratosphere UT/LS (IGAC, 2007, and references therein), the CARIBIC project aims at routine measurements of a broad suite of atmospheric trace gases and aerosol properties (Brenninkmeijer et al., 2007). Carbon monoxide, after ozone, is likely the second most measured atmospheric trace gas, and is essential to characterize the chemical composition, origin, and fate of the sampled air masses (WMO, 2010). Throughout the troposphere, $\mathrm{CO}$ is a major reaction partner in the photochemical cycles that control the concentrations of $\mathrm{O}_{3}$ and $\mathrm{OH}$ radicals and by this the oxidation capacity of the atmosphere (e.g. Logan et al., 1981; Parrish et al., 1998). It is emitted directly mostly from inefficient burning of fuels and is produced as an intermediate of photo-oxidation of volatile organic compounds (e.g. Duncan et al., 2007). It has a relatively long atmospheric lifetime, ranging at mid-latitudes from about 2 weeks in summer to several months in winter (Warneck, 1988), and is thus an excellent tracer for long-range transport (e.g. Smyth et al., 1999; Jacob et al., 2003; Jiang et al., 2007). Furthermore, $\mathrm{CO}$ is frequently used as a valuable tracer for anthropogenic pollution, as well as emissions from biomass and biofuel burning (e.g. Mauzerall et al., 1998; Smyth et al., 1999; Szopa et al., 2007).

The CO mixing ratio in the UT/LS varies from less than $30 \mathrm{ppbv}$ in the lowermost stratosphere to more than $500 \mathrm{ppbv}$ in the plumes of biomass burning (e.g. Mauzerall et al., 1998; Zahn et al., 2002a), and such contrasts can be found within distances of a few $\mathrm{km}$ when cutting through tropopause folds (e.g. Zahn et al., 2000; Roiger al., 2011). Combined with a cruising speed of typically $870 \mathrm{~km} \mathrm{~h}^{-1}\left(240 \mathrm{~m} \mathrm{~s}^{-1}\right)$ and unattended operation during a sequence of several flights, the CARIBIC instrument has to be fast, precise, accurate, and reliable.

$\mathrm{CO}$ is commonly measured by commercial instruments based on non-dispersive infrared absorption spectroscopy (NDIR), gas chromatography coupled with an $\mathrm{HgO}$ or flame ionization detector (FID) (by reducting $\mathrm{CO}$ to $\mathrm{CH}_{4}$ ), and 
by resonance fluorescence in the vacuum ultraviolet (VUVRF) (Zellweger et al., 2009 and references therein). These four techniques were inter-compared at the high-altitude Jungfraujoch observatory (Switzerland) and found to agree within $2 \%$ for one-hourly averages. Increasingly used are commercial instruments based on wavelength-scanned cavity ring-down spectroscopy (WS CRDS, Provencal et al., 2005; WMO, 2010). The original tunable diode laser absorption spectroscopy (TDLAS) was pioneered by several groups for research aircraft applications (Sachse et al., 1987; Wienhold et al., 1998). Indeed, at least three of these techniques (NDIR, TDLAS, VUVRF) are still used onboard aircraft, with their specific advantages and disadvantages (Nedelec et al., 2003; Holloway et al., 2000).

During the first phase of CARIBIC from 1997 to 2002, $\mathrm{CO}$ was measured by a gas chromatograph with $\mathrm{HgO}$ detector with a temporal resolution of $112 \mathrm{~s}$ corresponding to a measurement every $\sim 30 \mathrm{~km}$ at cruising altitude (Zahn et al., 2002a). But as was well known, also because of concurrent highly resolved ozone measurements $(1 \mathrm{~s})$, small scale CO features are abundant. To better resolve the corresponding variations of $\mathrm{CO}$ concentrations and to cover the large span of the encountered mixing ratios, a fast linear response vacuum UV resonance fluorescence instrument (Volz and Kley, 1985; Gerbig et al., 1996 and 1999; Holloway et al., 2000) was developed for the second phase of CARIBIC starting in December 2004. In this paper we describe the modifications of a commercially available instrument and its performance over more than 7 years of operation and finally assess the data quality.

\section{The CARIBIC container}

The CARIBIC container housing altogether 15 instruments is flown aboard one of Lufthansa's Airbus 340-600. This aircraft was mechanically and electrically modified and equipped with a permanent air inlet system in November 2004 (Brenninkmeijer et al., 2007). The CARIBIC measurement container is deployed monthly on four consecutive long-range flights, such as Frankfurt - Caracas - Frankfurt - Osaka - Frankfurt, totaling about 40 flight hours. Each instrument in the container is equipped with its own computer that controls the measurement process and collects data. The instruments communicate via an Ethernet bus system with a master computer for control purposes. The master computer collects via the ARINC-429 bus system aircraft data on position, temperature, pressure, wind and some other parameters and records internal status data on temperatures at different places in the container and pressures at different points within the air sampling and distribution system. The communication between the master computer and the instruments is recorded and used for post-flight synchronization of the measurements. To avoid contamination of the instruments by strongly polluted air near airports, pumping systems are powered only above a pressure altitude of $750 \mathrm{hPA}(\sim 2.5 \mathrm{~km}$. Like all equipment in the CARIBIC container, the $\mathrm{CO}$ analyzer had to pass a thorough safety certification process for the use onboard a civil aircraft, including tests of radiated and conducted electromagnetic interference (DO-160), and documentation with calculations to prove conformity with mechanical and electrical requirements as well as with the regulations of the use of hazardous materials.

\section{CO instrument and its modifications}

The fast-response UV resonance fluorescence (RF) instrument is based on a resonance-fluorescence of the $A^{1} \Pi \rightarrow$ $X^{1} \Sigma$ transition of $\mathrm{CO}$ in the vacuum UV range around $150 \mathrm{~nm}$ (Volz and Kley, 1985). The instrument (Model AL 5002, Aero-Laser, Garmisch-Partenkirchen, Germany) is an improved version of the instrument described in detail by Gerbig et al. (1999). It uses a discharge resonance lamp excited by radio frequency (rf) radiation. Its light $(135-175 \mathrm{~nm})$ is collimated by an off-axis parabolic mirror into an optical filter consisting of 2 dielectric mirrors in series which confine the excitation wavelength to about $143-155 \mathrm{~nm}$. The light beam is then focused by another off-axis parabolic mirror into the fluorescence cell. The fluorescent light with a wavelength ranging from 150 to $220 \mathrm{~nm}$ is imaged by a combination of two Suprasil lenses onto the photocathode of a small side-on photomultiplier tube with Suprasil window (Hamamatsu R6354). Suprasil optics and photomultiplier window block all excitation light below $175 \mathrm{~nm}$. The use of the offaxis parabolic mirrors in the Aero-Laser instrument instead of the $\mathrm{CaF}_{2}$ lenses shown in Fig. 1 of Gerbig et al. (1999) further improved the transmission of the excitation optics. The replacement of the original Hamamatsu R759 photomultiplier by R6354 improved the maximum quantum efficiency from about 15 to $35 \%$.

Figure 1 shows schematically the lay-out of the sample air flow through the instrument. Sample air is taken from the trace gas probe diffuser tube using a perpendicular $3 / 8^{\prime \prime}$ PFA lined pick up tube (heated to $40^{\circ} \mathrm{C}$ ) (Brenninkmeijer et al., 2007). The trace gas sampling line from the inlet, which is mounted underneath the aircraft in front of the measurement container, likewise is fitted with a PFA liner and all tubing is heated. Depending on the cruising altitude, the air sample inlet pressure (sum of ambient and ram pressure) varies between $\sim 220$ and $300 \mathrm{hPa}$. The pressure in the fluorescence cell is kept constant at $10 \mathrm{hPa}$ by a back pressure controller (P.C.) at its entrance. Down-flow of the pressure controller, the sample air is directed either via a needle valve or via a zero-air trap (stainless steel tube, ID $10 \mathrm{~mm}$ ) filled with $9.1 \mathrm{~g}$ of Sofnocat (Molecular Products Ltd.) catalyst (Foulger and Simmonds, 1993) into the fluorescent cell. The needle valve (NV) is adjusted to match the flow resistance of the parallel zero-air trap. The air from the optical cell and the gas 

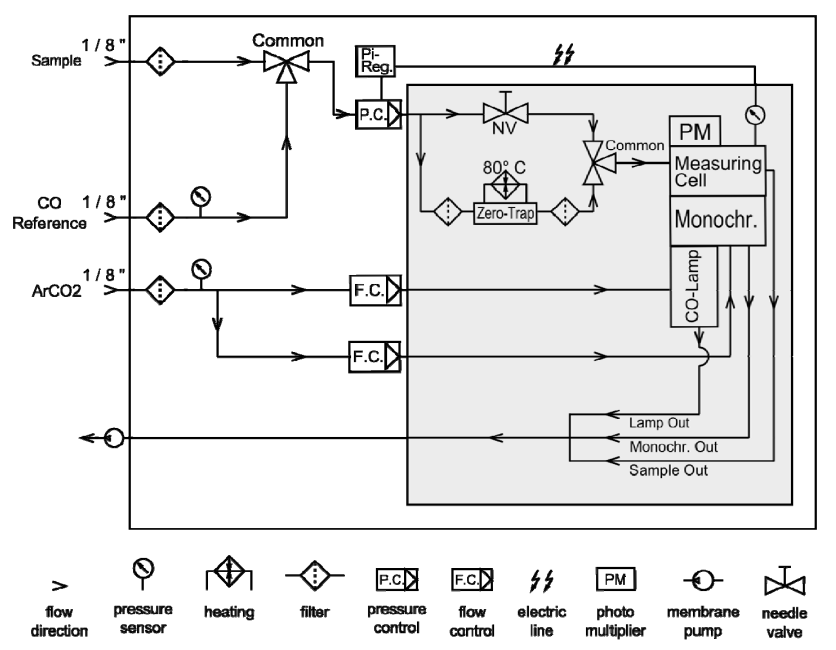

Fig. 1. Flow scheme of the CARIBIC CO instrument. The individual components are described below the sketch.

from the rf discharge is disposed by a diaphragm pump (Vacuubrand, MD4) installed in the CARIBIC container.

The following modifications have been made to the device.

The original housing of the instrument was replaced by an electromagnetic interference (EMI) proofed 19" housing (W $480 \times \mathrm{D} 600 \times \mathrm{H} 177 \mathrm{~mm}$ ) with additional space for DC/DC converters, an EMI filter, an RS-232 to Ethernet converter that interfaces the instrument to the container data bus (custom made RS485 with Code Division Multiple Access), memory cards for housekeeping data and signals, and aircraft fuse/switch (ETA Model 482).

The original $\mathrm{CaF}_{2}$ lamp window was replaced by a $\mathrm{MgF}_{2}$ window because of its higher VUV transmission (Samson, 1967). The detector window of the cell was originally sealed using an adhesive. This sealing frequently caused leaks, probably because of the large temperature variations of the instrument ranging from less than $15^{\circ} \mathrm{C}$ to occasionally over $35^{\circ} \mathrm{C}$ depending on ambient conditions. A Viton o-ring seal fitting installed in the existing groove solved this problem.

An additional three-way valve (top left corner of Fig. 1) in the internal inlet tubing of the instrument enables the measurement of calibration gas during the flight. The back pressure controller at the entrance of the fluorescence cell keeps the pressure in the cell constant even if the pressures of the sample air and the calibration gas are different. We found that the calibration gas becomes contaminated during the period of up to a few days between the final preflight conformation test of the container and the first flight, which lead to excessive drifts in zero and calibration signals during the first two calibration cycles. The contamination was dependent on the type and manufacturer of the pressure regulator used on the cylinder filled with $\mathrm{CO}$ calibration gas. The contamination from a stainless steel membrane pressure regulator manufactured by AGA was the smallest of the tested regulators but still did not allow reliable measurements during the first two calibration cycles. Flushing the calibration gas tubing three times with the calibration gas a few hours before the first flight removed this problem.

We do not apply drying of the sample air, as usually done by using Nafion driers or Drierite (e.g. Holloway et al., 2000), because the air at altitudes between 9 and $12 \mathrm{~km}$ is dry. The typical mixing ratios of water vapor at the altitudes are 10-100 ppmv, with very rare and short episodes reaching 1000 ppmv (Schuck et al., 2009). According to Gerbig et al. (1999), such low humidity does not influence the signal. We have replicated their laboratory test and, as they, found no change in zero air and calibration gas signals by saturating zero air and calibration gas with water at $20^{\circ} \mathrm{C}$ (which corresponds to $\sim 20000$ ppmv $\mathrm{H}_{2} \mathrm{O}$ ).

Until February 2010 the optical path between the lamp and the fluorescence cell as well as between the cell and the photomultiplier had been flushed by nitrogen to eliminate the absorption of the lamp light by oxygen. To reduce the number of gas cylinders in the container, the already installed cylinder filled with a gas mixture of $0.25 \% \mathrm{CO}_{2}$ in Ar initially only used to supply the discharge lamp was from then on also used for flushing the outside optical path. This change reduced the sensitivity of the instrument by less than $2 \%$. Both the lamp and the optics flushing flow rates are kept constant at $30 \mathrm{~cm}^{3} \mathrm{~min}^{-1}$ STP using flow controllers.

The sample and calibration gas flow rates are set to $\sim 100 \mathrm{~cm}^{3}$ (STP) $\mathrm{min}^{-1}$. To sustain the flows of sampling gas, flushing gas, and lamp gas up to an altitude of $12 \mathrm{~km}$, a more powerful pump (Vacuubrand Model MD4) than supplied was installed. We also increased the operating temperature of the Sofnocat catalyst from ambient to $80^{\circ} \mathrm{C}$. Sofnocat is usually operated at ambient pressure and temperature, but we operate it at low pressure slightly above the pressure in the measuring cell, i.e. at $\sim 10 \mathrm{hPa}$. The resulting reduction of contact time by a factor of $\sim 100$ in a cartridge of the same volume is compensated by higher operating temperature.

The modified instrument now weighs $20.5 \mathrm{~kg}$ and consumes less than $450 \mathrm{~W}$ (28 VDC) during the warm-up and $\sim 200 \mathrm{~W}$ during the continuous operation. To avoid problems with radiated and conducted electromagnetic interference, the entire assembly of the rf generator, the lamp, the fluorescent cell, and the photomultiplier was made radio frequency tight. An additional EMI filter (Yumpen model YC06T1L2) at the power socket blocks the conducted interference. The instrument underwent extensive tests on conducted and emitted electromagnetic interference based on DO-160 regulation on 2 occasions as a part of the entire container instrumentation in a large certified EMI facility.

The original detector signal, i.e. the count frequency, and the status signals such as the pressure in the cell, the flow rates, and the temperatures of the photomultiplier and the lamp are recorded (count frequency with $1 \mathrm{~Hz}$, status signals with $0.1 \mathrm{~Hz}$ ) and processed in a post-flight data analysis. The instrument is calibrated in-flight every 25 min using a working standard with a nominal mixing ratio of $250 \mathrm{ppbv} \mathrm{CO}$ in 


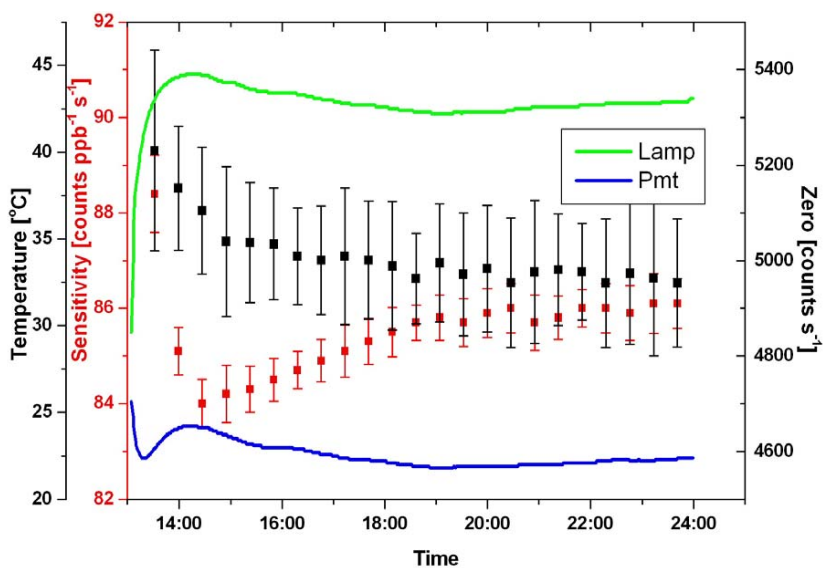

Fig. 2. Sensitivity (red), zero signal (black, right y-axis), and temperatures of the photomultiplier (blue) and of the lamp (green) during flight \#347 from Frankfurt to Bogotá on 16 June 2011. The temperatures were recorded continuously, while the zero signal and the sensitivity were only measured during the calibration cycles every $25 \mathrm{~min}$. The error bars give the $1 \sigma$ variation during the last $60 \mathrm{~s}$ of each calibration cycle.

air (Scott Marrin). The calibration cycle consists of a calibration measurement for $80 \mathrm{~s}$ followed by zero measurement for another $80 \mathrm{~s}$. Only the final $60 \mathrm{~s}$ averages of each calibration and zero measurement are taken for calculating the zero signal and sensitivity. The CO mixing ratio during flight is calculated from

$\mathrm{CO}=\left(\mathrm{S}-\mathrm{S}_{\text {zero }}\right) \times \mathrm{CO}_{\text {cal }} /\left(\mathrm{S}_{\text {cal }}-\mathrm{S}_{\text {zero }}\right)$

where $\mathrm{CO}_{\text {cal }}$ is the mixing ratio of calibration gas, $\mathrm{S}$ the measured signal, and $S_{\text {zero }}$ and $S_{\text {cal }}$ are zero and calibration signals, respectively, linearly interpolated between the calibrations bracketing the measurement interval of $25 \mathrm{~min}$.

\section{Long-term performance during CARIBIC flights}

The instrument temperature, which in turn depends on the temperature of the cargo bay, is the major parameter influencing the zero and span signals. As an example, Fig. 2 shows the instrument sensitivity (defined as $\left.\left(\mathrm{S}_{\mathrm{cal}}-\mathrm{S}_{\mathrm{zero}}\right) / \mathrm{CO}_{\mathrm{cal}}\right)$ and the zero signal measured during the different calibration sequences as well as the continuously measured temperatures of the photomultiplier and the lamp during flight \#347 from Frankfurt to Bogotá on 16 June 2011. During the $\sim 10$ h flight the instrument sensitivity and zero signal varied by $\sim 5 \%$ and $4 \%$, respectively. The origin of these drifts could not be unambiguously delimited. There is a negative correlation of both parameters with the temperatures of the photomultiplier and the lamp in the order of $-1 \% \mathrm{~K}^{-1}$. The temperature dependence of the photomultiplier sensitivity and dark count specified by Hamamatsu are far too small to account for this drift. We rather believe that the temperature of the lamp and the following optics (alignment) causes a relevant change in the light intensity and/or light transmission to the measurement cell. Gerbig et al. $(1996,1999)$ also found a strong correlation of the sensitivity or light intensity, respectively, with the pressure in the lamp that in turn is influenced by the lamp temperature. The drifts shown in Fig. 2 are typical for most of the flights with controlled cargo bay temperature. The temperature of the cargo bay was not well controlled during several flights and in these cases the drifts of span and zero signals could be twice as large.

During this flight \#347 the average span and zero signals amounted to 27246 and 5011 counts s $^{-1}$, respectively, which with a $260.4 \mathrm{ppb}$ calibration mixing ratio results in a sensitivity of 85.4 counts ppbv ${ }^{-1} \mathrm{~s}^{-1}$, which is a factor of $\sim 50$ higher compared to the first instruments described by Volz and Kley (1986) and Gerbig et al. (1996) but comparable to the improved instrument described by Gerbig et al. (1999). The zero signal corresponds to $59 \mathrm{ppb}$ and is lower than $\sim 85 \mathrm{ppb}$ of the instrument of Gerbig et al. (1999). The zero signal noise of \pm 70 counts $^{-1}$ thus causes a noise of $\sim 0.8 \mathrm{ppbv}$ at $1 \mathrm{~s}$. The additional noise from the photon statistics certainly depends on the $\mathrm{CO}$ concentration and varies between $0.59 \mathrm{ppbv}$ at $1 \mathrm{~s}$ and $30 \mathrm{ppbv}(30 \mathrm{ppbv} / \sqrt{30} \cdot 85.4)$ and $1.53 \mathrm{ppbv}$ at $1 \mathrm{~s}$ and $200 \mathrm{ppbv}(200 \mathrm{ppbv} / \sqrt{200} \cdot 85.4)$. The ambient mixing ratios of 30 and 200 ppbv can thus be measured with a precision of $\sim 1.2$ and $\sim 2.1 \mathrm{ppbv}$, respectively.

This high precision due to photon statistic is also reached during flight. During flight \#116 from Santiago de Chile to São Paulo on 21 June 2005, the CARIBIC aircraft sampled an extremely well-mixed flight section close to the tropopause of the Southern Hemisphere from 18:47:41 to 19:11:52 UTC, i.e. over $\sim 24 \mathrm{~min}$, and measured an almost constant CO mixing ratio of $47.9 \pm 1.6$ ppbv. Counting statistics suggested a precision of $0.65 \mathrm{ppbv}(47.9 \mathrm{ppbv} / \sqrt{47.9}$. 115 ) plus the zero signal noise of $\sim 0.7 \mathrm{ppbv}$ (see above), which in sum is only slightly less than the measured noise of $1.6 \mathrm{ppbv}$. This measured standard deviation is the sum of instrument noise and atmospheric variability over the quite long sampling period of $\sim 24 \min$ (or $\sim 350 \mathrm{~km}$ along the flight path). We can thus conclude that the precision of the $\mathrm{CO}$ measurements during the regular CARIBIC flights is determined by counting statistics which are controlled by the instantaneous sensitivity.

A further crucial feature is the long-term stability of the device, i.e. the change in the zero signal and sensitivity during the regular CARIBIC flights. Figure 3 shows the zero signal and sensitivity for all CARIBIC flights between May 2005 and December 2011. The zero signal and sensitivity decreased strongly from the initial values of $\sim 115$ counts s ${ }^{-1} \mathrm{ppbv}^{-1}$ and 4500 counts s$^{-1}$, respectively, in May 2005 to less than 15 counts s$~^{-1}$ ppbv $^{-1}$ and 1000 counts s ${ }^{-1}$ in May 2008, respectively. The precision of the CO measurements deteriorated correspondingly with the worsening photon statistics from initial $0.5 \mathrm{ppbv}$ to $2 \mathrm{ppbv}$ for $1 \mathrm{~s}$ integrating time. The dark photomultiplier signal remained constant at 76 counts $^{-1}$ (not shown), implying that the lamp or the 


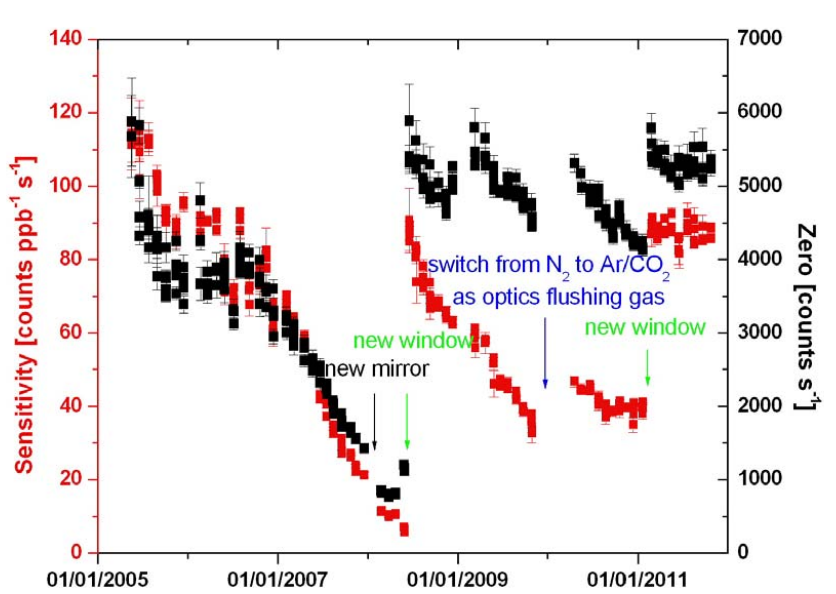

Fig. 3. Long-term progression of the zero signal and the sensitivity during the use onboard the CARIBIC aircraft. The points represent the averages over the duration of each flight (typically of 9-12 h) and the error bars their standard deviation. Instrument maintenance (see text): (1) replacement of the off-axis parabolic mirror (February 2008), (2) replacement of the $\mathrm{MgF}_{2}$ lamp window (June 2008 and February 2011), (3) switch from $\mathrm{N}_{2}$ to $\mathrm{Ar} / \mathrm{CO}_{2}$ (December 2009) as a flushing gas for the optics.

transmission of the optical system deteriorated over the three years of use. Figure 3 shows that the relation between the zero and sensitivity deterioration and the number of operating hours is not linear, suggesting that other factors might also play a role such as the purity of the $\operatorname{argon} / \mathrm{CO}_{2}$ gas mixture used to operate the lamp.

To restore the sensitivity, first the parabolic off-axis mirror collimating the light of the lamp was changed in February 2008 with hardly any effect. The original sensitivity was, however, nearly restored by renewing the $\mathrm{MgF}_{2}$ window of the lamp in June 2008. Inspection of the old window under a microscope revealed a four dot grey-brown pattern coinciding with the four gas inlet holes. Grinding and polishing of the exposed side of the window did neither remove the pattern, nor restored the original sensitivity or light intensity, respectively. We thus surmise that the transparency of this window had been impaired by the formation of color centers as had been observed when using LiF windows (Samson, 1967; Warneck, 1965). The sensitivity decreased again after June 2008 until October 2009, although the zero signal did not change much during this period. From May 2010 until February 2011 the sensitivity remained nearly constant, whereas the zero signal decreased by some $20 \%$. The exchange of the MgF2 window in February 2011 restored the original sensitivity again and led to somewhat higher zero signal, both of which remained nearly constant afterwards. We thus conclude that the actual property of the $\mathrm{MgF}_{2}$ lamp window largely determines the sensitivity of the device and has to be exchanged after a certain period of operation. Based on our experience (Fig. 3), the transmission of the $\mathrm{MgF}_{2}$ lamp

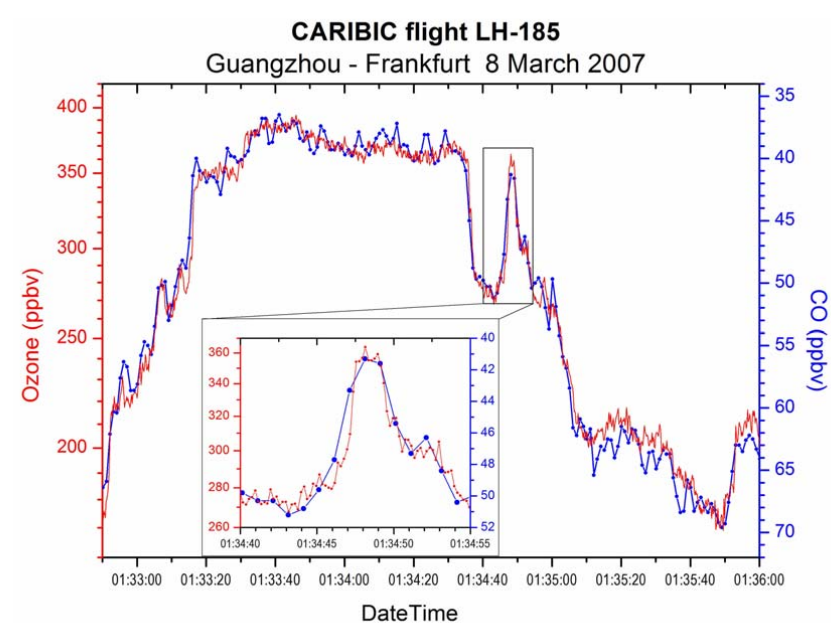

Fig. 4. Fast changes of $\mathrm{CO}$ and $\mathrm{O}_{3}$ concentrations during a section of flight \#185 from Guangzhou to Frankfurt on 8 March 2007. Note the inverse scale for $\mathrm{CO}$. The insert shows a 90 ppbv $\mathrm{O}_{3}$ peak, with a coinciding $8 \mathrm{ppbv}$ drop in $\mathrm{CO}$ over a period of only $\sim 12 \mathrm{~s}$ (blue dots).

window decreased by $\sim 3 \%$ per flight sequence of four consecutive long-range flights, i.e. altogether 30-40 flight hours.

The response time of the instrument, here the time to reach $63.2 \%$ of the final signal, was determined to be $2 \mathrm{~s}$ by stepwise increasing the concentration during a test in the laboratory. The stepwise reduction of the concentration yielded the same response time of $2 \mathrm{~s}$. Figure 4 shows an actual case onboard the CARIBIC aircraft, namely $\mathrm{O}_{3}$ and $\mathrm{CO}$ measurements during a section of flight \#185 from Guangzhou to Frankfurt on 8 March 2007. The aircraft flew through a very thin laminae structure, most likely generated by a gravity wave, concomitant with rapid changes of $\mathrm{O}_{3}$ which were tightly anti-correlated with $\mathrm{CO}$. The reason for the anticorrelation is mixing of stratospheric air with high $\mathrm{O}_{3}$ and low $\mathrm{CO}$ with tropospheric air with high $\mathrm{CO}$ and low $\mathrm{O}_{3}$. Ozone was measured by a fast chemiluminescence instrument with a temporal resolution of $0.2 \mathrm{~s}$ (Zahn et al., 2002b; Brenninkmeijer et al., 2007). The ozone peak at 1:34:48 UTC was accompanied by a sharp dip in the $\mathrm{CO}$ mixing ratios, confirming that the response time in flight is indeed about $2 \mathrm{~s}$.

Linearity of the instrument was tested off-line using a 15 ppmv CO in air calibration gas (Scott Marrin) diluted by zero air to get a range of 43.5 to $290.6 \mathrm{ppbv}$ of CO. The deviation from the linearity varied between -0.9 at the lowest and $+0.7 \%$ at the highest concentrations, and the average deviation over the tests concentration range was with $0.3 \pm 0.5 \%$ insignificant. 
Table 1. Results of a round-robin experiment with EMPA (Switzerland) and NOAA (US). The MPI instrument was calibrated with a standard of $155.8 \pm 0.5 \mathrm{ppbv}$ which was referenced to the EMPA standard cylinder CA06490 with 352.5 ppbv CO. The MPI results are reported with expanded uncertainty resulting from the standard deviation of the individual measurements and the uncertainty of the MPI standard.

\begin{tabular}{lccc}
\hline Cylinder & $\begin{array}{c}\text { MPI 2010 } \\
{[\mathrm{ppb}]}\end{array}$ & $\begin{array}{c}\text { EMPA 2008 }^{\mathrm{a}} \\
{[\mathrm{ppb}]}\end{array}$ & $\begin{array}{c}\text { NOAA 2008 } \\
{[\mathrm{ppb}]}\end{array}$ \\
\hline CA 08179 & $74.6 \pm 0.5$ & $73.0 \pm 0.5$ & $72.5 \pm 0.5$ \\
CA 06529 & $102.6 \pm 0.5$ & $101.9 \pm 0.6$ & $101.6 \pm 0.7$ \\
CA 08161 & $164.6 \pm 0.7$ & $162.3 \pm 0.6$ & $161.3 \pm 1.1$ \\
CA 08136 & $230.5 \pm 0.8$ & $227.5 \pm 1.0$ & $224.6 \pm 1.5$ \\
CC 113562 & $296.7 \pm 1.1$ & $296.2 \pm 1.0$ & $294.0 \pm 2.0$ \\
CA 08193 & $401.1 \pm 1.5$ & $398.5 \pm 1.0$ & $395.2 \pm 2.7$ \\
\hline
\end{tabular}

a analytical precision

$\mathrm{b}$ includes estimate of uncertainty in the scale

\section{Accuracy of the CARIBIC CO data}

The accuracy of $\mathrm{CO}$ measurements has been an ongoing challenge (e.g. Novelli et al., 2003) in general. The main reason is the drift in CO standards as mixtures are often not stable in high-pressure gas cylinders. The non-linearity of the $\mathrm{HgO}$ detectors used frequently in the past as the sole detector system have contributed to further uncertainties. Table 1 presents the results of a main round-robin experiment involving a large number of laboratories, including EMPA (Switzerland, WMO audit institution) and NOAA-ESRL (US, the supplier of standard mixtures based on gravimetry). The results of our Max Planck Institute (MPI) are given with the combined uncertainties of measurement and calibration, the EMPA results with their analytical precision, and the NOAA results that include an estimate of uncertainty in the CO scale (WMO, 2010). Most of the MPI measurements agree within the given uncertainties with those by EMPA. This is not surprising given that the MPI calibration standard of $155.8 \pm 0.5 \mathrm{ppb}$ was tied to EMPA standard of $352.5 \mathrm{ppb}$ (cylinder CA 06490). Differences between MPI and NOAA measurements are somewhat larger, but considering the individual uncertainties given by both laboratories, they still lie mostly within the WMO data quality objectives (DQO) of \pm 2 ppbv for measurements in marine boundary layer and at other remote sites (WMO, 2010).

The round-robin experiment confirmed that the old MPI gas standard mixture from Scott Marin with a nominal mixing ratio of $250 \mathrm{ppbv}$ had in fact a mixing ratio of $263.5 \mathrm{ppb}$, i.e. was $5.4 \%$ higher. Consequently, all CARIBIC phase 2 measurements (since May 2005) published up until March 2010 must be corrected by a factor of 1.054 . From then on all data provided are on the NOAA 2004 scale.
The total uncertainty of the individual $\mathrm{CO}$ measurements can be estimated by uncertainty propagation of variables from Eq. (1) as follows:

$\frac{d \mathrm{CO}}{\mathrm{CO}}=$
$\sqrt{\left(\frac{d \mathrm{CO}_{\text {cal }}}{C \mathrm{O}_{\text {cal }}}\right)^{2}+\left(\frac{d \mathrm{~S}}{\mathrm{~S}-\mathrm{S}_{\text {zero }}}\right)^{2}+\left(\frac{d \mathrm{~S}_{\text {cal }}}{\mathrm{S}_{\text {cal }}-\mathrm{S}_{\text {zero }}}\right)^{2}+\left(\frac{\left(\mathrm{S}_{\text {cal }}-\mathrm{S}\right) \times d \mathrm{~S}_{\text {zero }}}{\left(\mathrm{S}_{\text {cal }}-\mathrm{S}_{\text {zero }}\right) \times\left(\mathrm{S}-\mathrm{S}_{\text {zero }}\right)}\right)^{2}}$

The uncertainty thus depends on the uncertainties of the signal $\mathrm{S}$, the calibration signal $\mathrm{S}_{\text {cal }}$, the zero signal $\mathrm{S}_{\text {zero }}$, the $\mathrm{CO}$ mixing ratio in the calibration gas $d \mathrm{CO}_{\text {cal }}$, and on the signal differences $\left(\mathrm{S}-\mathrm{S}_{\mathrm{zero}}\right),\left(\mathrm{S}_{\mathrm{cal}}-\mathrm{S}_{\mathrm{zero}}\right)$, and $\left(\mathrm{S}_{\mathrm{cal}}-\mathrm{S}\right)$. As $\mathrm{S}_{\mathrm{cal}}$ and $S_{\text {zero }}$ vary from flight to flight (as shown in Fig. 3) and during the flight (see Fig. 2), the uncertainty has to be calculated for each section sandwiched between two calibrations.

In addition to random uncertainties, $d \mathrm{~S}, d \mathrm{~S}_{\text {cal }}$, and $d \mathrm{~S}_{\text {zero }}$ which are governed by photon statistics and which are considered in Eq. (1), systematic uncertainties originating from drifts in sensitivity and zero signals also have to be considered. To account for these drifts we interpolate $S_{\text {cal }}$ and $S_{\text {zero }}$ between adjacent calibrations (except where no previous or subsequent calibration is available). This procedure will eliminate the uncertainties caused by drifts in $S_{\text {cal }}$ and $\mathrm{S}_{\text {zero }}$ when the drifts are linear and/or small, which is the case for most sections of a flight. Stronger and partially unlinear drifts occur only during the warm-up phase at flight start (see Fig. 2). The assumption of linear drift in such cases might lead to a systematic uncertainty that is difficult to quantify but is surely much smaller than the differences of $S_{c a l}$ and $S_{\text {zero }}$ of 4.0 and $1.5 \%$, respectively, of the first two calibrations in Fig. 2.

For illustration we calculate the random uncertainty of CO measurements during the flight \#347. The calibration gas used during this flight had $260.4 \pm 3.0 \mathrm{ppbv}$ mixing ratio. The uncertainty of $\mathrm{CO}$ measurements with $1 \mathrm{~s}$ resolution from Eq. (2) was $3.3 \%$ at an average $\mathrm{CO}$ mixing ratio of 43 ppbv during the 13:35-14:00 section in the stratosphere and $2.4 \%$ at an average $\mathrm{CO}$ mixing ration of 83 ppbv during the 18:10 - 18:35 section in the troposphere. These estimates are upper limits as we used $1 \mathrm{~s}$ photon statistics for $d \mathrm{~S}_{\mathrm{cal}}$ and $d \mathrm{~S}_{\text {zero }}$, while the use of standard average error for $60 \mathrm{~s}$ would be more appropriate. The above uncertainty estimates can be generalized by claiming an uncertainty of smaller than $3 \%$ for most tropospheric measurement with $1 \mathrm{~s}$ resolution made during the flights when the instrument had a sensitivity of $\sim 80$ counts $\mathrm{ppb}^{-1} \mathrm{~s}^{-1}$ and more. To achieve approximately the same uncertainty during the flights when the instrument had a reduced sensitivity of 40 and 20 counts $\mathrm{ppb}^{-1} \mathrm{~s}^{-1}$, the signals have to be integrated over 2 and $4 \mathrm{~s}$, respectively. Larger uncertainty of less than $5 \%$ in the stratosphere is due to worse photon statistics at lower $\mathrm{CO}$ mixing ratios.

Since May 2005, altogether 250 CARIBIC flights have been conducted. The $\mathrm{CO}$ instrument has failed during 7 flights, which results in its availability of $97 \%$. During 3 individual flights the data loss can be attributed to instrument 
malfunction: during one flight the lamp did not ignite and during two flights the flow controllers did not work. All other data loss were due to external factors such as a switched-off pump due to malfunction of the system controller.

A practical problem in the operation of the instrument remains the ignition of the discharge lamp. On average, it takes $\sim 11$ min to ignite the lamp but on occasion it may take only $1 \mathrm{~min}$ or as much as $30 \mathrm{~min}$. We tried and failed to get a faster and more predictable ignition by repeated readjusting the rf coupling to the discharge capillary. This can be done now only when the lamp encasement is open. We note that the encasement itself is a part of the rf resonator and the adjustment should be possible from outside without opening it, e.g. by screws, as is the usual practice with microwave resonators (Samson, 1967).

\section{Conclusions}

The commercial vacuum UV resonance fluorescence instrument with modifications described here has proved to be able to provide fast ( $2 \mathrm{~s}$ response time) and accurate (within \pm 2 ppbv data quality objectives stipulated by WMO (2010)) measurements of $\mathrm{CO}$ mixing ratios onboard the CARIBIC passenger aircraft. The experience accumulated over more than 6 years of operation shows that the instrument was reliable with $97 \%$ data availability. Decreasing sensitivity and zero signals were attributed to the deteriorating transparency of the $\mathrm{MgF}_{2}$ entrance window of the fluorescent cell and could be restored by replacing this window. Owing to the loss of transparency of $\sim 3 \%$ per flight sequence of four consecutive long range flights observed during CARIBIC, it is advised to do this regularly. During CARIBIC with $\sim 5$ operational days per month (including ground tests), this window exchange has to be done each 1.5 years. The lifetime of the window may depend on the purity of the gas with which the lamp is operated and on the operating conditions. On this point we have no solid information from other users of this type of instrument. Although the problem of unpredictable and sometimes long delay before ignition of the rf discharge in the lamp has not been resolved so far, the overall performance and use of this instrument is satisfactory.

The high reliability and robustness, simple use, fast measurement speed of $\sim 1 \mathrm{~s}$ as well as high precision (1-2 ppbv at $1 \mathrm{~s}$ ) and accuracy make this device particularly suitable for the use onboard aircraft. Other commercially available techniques using gas chromatography and NDIR cannot compete with its measurement speed. Custom-made systems applying, e.g. TDLAS in the mid-infrared (Sachse et al., 1987, Wienhold et al., 1998), do show a comparable performance, but are much more complex and require skilled personnel for its use. Recently, a CRDS instrument has been reported to have achieved a precision of $0.2 \mathrm{ppbv}$ with $1 \mathrm{~s}$ time resolution onboard aircraft, accompanied by nearly care-free operation (Provencal et al., 2005). We are not aware of any long-term experience with this instrument. Also, commercial equipment with a comparable high performance, based on $\mathrm{CRD}$, is becoming available.

Acknowledgements. We thank Paul Novelli, NOAA-ESRL, for the many years of support doing $\mathrm{CO}$ measurements.

The service charges for this open access publication have been covered by the Max Planck Society.

Edited by: D. Feist

\section{References}

Brenninkmeijer, C. A. M., Crutzen, P., Boumard, F., Dauer, T., Dix, B., Ebinghaus, R., Filippi, D., Fischer, H., Franke, H., Frieß, U., Heintzenberg, J., Helleis, F., Hermann, M., Kock, H. H., Koeppel, C., Lelieveld, J., Leuenberger, M., Martinsson, B. G., Miemczyk, S., Moret, H. P., Nguyen, H. N., Nyfeler, P., Oram, D., O’Sullivan, D., Penkett, S., Platt, U., Pupek, M., Ramonet, M., Randa, B., Reichelt, M., Rhee, T. S., Rohwer, J., Rosenfeld, K., Scharffe, D., Schlager, H., Schumann, U., Slemr, F., Sprung, D., Stock, P., Thaler, R., Valentino, F., van Velthoven, P., Waibel, A., Wandel, A., Waschitschek, K., Wiedensohler, A., Xueref-Remy, I., Zahn, A., Zech, U., and Ziereis, H.: Civil Aircraft for the regular investigation of the atmosphere based on an instrumented container: The new CARIBIC system, Atmos. Chem. Phys., 7, 4953-4976, doi:10.5194/acp-7-4953-2007, 2007.

Duncan, B. N., Logan, J. A., Bey, I., Megretskaia, I. A., Yantosca, R. M., Novelli, P. C., Jones, N. B., and Rinsland, C. P.: Global Budget of CO, 1988-1997: Source estimates and validation with a global model, J. Geophys. Res., 112, D22301, doi:10.1029/2007JD008459, 2007.

Foulger, B. E. and Simmonds, P. G.: Ambient temperature gas purifier suitable for the trace analysis of carbon monoxide and hydrogen and the preparation of low-level carbon monoxide calibration standards in the field, J. Chromatog., 630, 257-263, 1993.

Gerbig, C., Kley, D., Volz-Thomas, A., Kent, J., Dewey, K., and McKenna, D. S.: Fast response resonance fluorescence CO measurements aboard the C-130: Instrument characterization and measurements made during North Atlantic Regional Experiment 1993, J. Geophys. Res., 101, 29229-29238, 1996.

Gerbig, C., Schmitgen, S., Kley, D., Volz-Thomas, A., Dewey, K., and Haaks, D.: An improved fast-response vacuum-UV resonance fluorescence CO instrument, J. Geophys. Res., 104, 16991704, 1999.

Holloway, J. S., Jakoubek, R. O., Parrish, D. D., Gerbig, C., VolzThomas, A., Schmidtgen, S., Fried, A., Wert, B., Henry, B., and Drummond, J. R.: Airborne intercomparison of vacuum ultraviolet fluorescence and tunable diode laser absorption measurements of tropospheric carbon monoxide, J. Geophys. Res., 105, 24251-24261, 2000.

IGAC: Special issue on routine measurements from mobile platforms (CARIBIC, MOZAIC, CONTRAIL, TROICA, cargo ships), IGAC Newsletters, 37, 2-30, 2007.

Jacob. D. J., Crawford, J. H., Kleb, M. M., Vonnors, V. S., Bendura, R. J., Raper, J. L., Sachse, G. W., Gille, J. C., Emmons, L., and Heald, C. L.: Transport and Chemical Evolution over the Pacific 
(TRACE-P) aircraft mission: Design, execution, and first results, J. Geophys. Res., 108, 9000, doi:10.1029/2002JD003276, 2003.

Logan, J. A., Prather, M. J., Wofsy, S. C., and McElroy, M. B.: Tropospheric chemistry: A global perspective, J. Geophys. Res., 86, 7210-7254, 1981.

Mauzerall, D. L., Logan, J. A., Jacob, D. J., Anderson, B. E., Blake, D. R., Bradshaw, J. D., Heikes, B., Sachse, G. W., Singh, H., and Talbot, B.: Photochemistry in biomass burning plumes and implications for tropospheric ozone over the tropical South Atlantic, J. Geophys. Res., 103, 8401-8423, 1998.

Nedelec, P., Cammas, J.-P., Thouret, V., Athier, G., Cousin, J.-M., Legrand, C., Abonnel, C., Lecoeur, F., Cayez, G., and Marizy, C.: An improved infrared carbon monoxide analyser for routine measurements aboard commercial Airbus aircraft: technical validation and first scientific results of the MOZAIC III programme, Atmos. Chem. Phys., 3, 1551-1564, doi:10.5194/acp-3-15512003, 2003.

Novelli, P. C., Masarie, K. A., Lang, P. M., Hall, B. D., Myers, R. C., and Elkins, J. W.: Reanalysis of tropospheric CO trends: Effects of the 1997 - 1998 wildfires, J. Geophys. Res., 108, doi:10.1029/2002JD003031, 2003.

Parrish, D. D., Trainer, M., Holloway, J. S., Yee, J. E., Warshawsky, M. S., Fehsenfeld, F. C., Forbes, G. L., and Moody, J. L.: Relationships between ozone and carbon monoxide at surface sites in the North Atlantic region, J. Geophys. Res., 103, 13357-13376, 1998.

Provencal, R., Gupta, M., Owano, T. G., Baer, D. S., Ricci, K. N., O'Keefe, A., and Podolske, J. R.: Cavity-enhanced quantumcascade laser-based instrument for carbon monoxide measurements, Appl. Opt., 44, 6712-6717, 2005.

Roiger, A., Schlager, H., Schäfler, A., Huntrieser, H., Scheibe, M., Aufmhoff, H., Cooper, O. R., Sodemann, H., Stohl, A., Burkhart, J., Lazzara, M., Schiller, C., Law, K. S., and Arnold, F.: Insitu observation of Asian pollution transported into the Arctic lowermost stratosphere, Atmos. Chem. Phys., 11, 10975-10994, doi:10.5194/acp-11-10975-2011, 2011.

Sachse, G. W., Hill, G. F., Wade, L. O., and Perry, M. G.: Fastresponse, high-precision carbon monoxide sensor using a tunable diode laser absorption technique, J. Geophys. Res., 92, 20712081, 1987.

Samson, J. A.: Techniques of vacuum ultraviolet spectroscopy, Wiley, New York, 1967.

Schuck, T. J., Brenninkmeijer, C. A. M., Slemr, F., Xueref-Remy, I., and Zahn, A.: Greenhouse gas analysis of air samples collected onboard the CARIBIC passenger aircraft, Atmos. Meas. Tech., 2, 449-464, doi:10.5194/amt-2-449-2009, 2009.
Smyth, S., Sandholm, S., Shumaker, B., Mitch, W., Kanvinde, A., Bradshaw, J., Liu, S., McKeen, S., Gregory, G., Anderson, B., Talbot, R., Blake, D., Rowland, S., Browell, E., Fenn, M., Merrill, J., Bachmeier, S., Sachse, G., and Collins, J.: Characterization of the chemical signatures of air masses observed during the PEM experiments over western Pacific, J. Geophys. Res., 104, 16243-16254, 1999.

Volz, A. and Kley, D.: A resonance fluorescence instrument for the in-situ measurement of atmospheric carbon monoxide, J. Atmos. Chem., 2, 345-357, 1985.

Warneck, P.: LiF color-center formation and uv transmission losses from argon and hydrogen discharges, J. Opt. Soc. Am., 55, 921925, 1965.

Warneck, P.: Chemistry of the Natural Atmosphere, Academic Press, New York, 1988.

Wienhold, F. G., Fischer, H., Hoor, P., Wagner, V., Königstedt, R., Harris, W. G., Anders, J., Grisar, R., Knothe, M., Riedel, W. J., Lübken, F.-J., and Schilling, T.: TRISTAR - a tracer in-situ TDLAS for atmospheric research, Appl. Phys. B, 67, 411-417, 1998.

WMO: Guidelines for the Measurement of Atmospheric Carbon Monoxide, GAW Report No. 192, WMO/TD-No. 1551, Geneva, July 2010.

Zahn, A., Brenninkmeijer, C. A. M., Maiss, M., Scharffe, D. H., Crutzen, P. J., Herrmann, M., Heintzenberg, J., Wiedensohler, A., Güsten, H., Heinrich, G., Fischer, H., Cuijpers, J. W. M., and van Velthoven, P. F. J.: Identification of extratropical tropospherestratosphere mixing based on CARIBIC measurements of $\mathrm{O}_{3}$, $\mathrm{CO}$ and ultra-fine particles, J. Geophys. Res., 105, 1527-1535, 2000.

Zahn, A., Brenninkmeijer, C. A. M., Crutzen, P. J., Heinrich, G., Fischer, H., Cuijpers, J. W. M., and van Velthoven, P. F. J.: Distribution and relationships of $\mathrm{O}_{3}$ and $\mathrm{CO}$ in the upper troposphere: The CARIBIC aircraft results 1997-2001, J. Geophys. Res., 107, 4337, doi:10.1029/2001JD001529, 2002a.

Zahn, A., Brenninkmeijer, C. A. M., Crutzen, P. J., Parrish, D. D., Sueper, D., Fischer, H., Heinrich, G., Güsten, H., Hermann, M., and Heintzenberg, J.: The origin of tropospheric "ozone clouds", J. Geophys. Res., 107, 4638, doi:10.1029/2002JD002345, 2002 b.

Zellweger, C., Hüglin, C., Klausen, J., Steinbacher, M., Vollmer, M., and Buchmann, B.: Inter-comparison of four different carbon monoxide measurement techniques and evaluation of the long-term carbon monoxide time series of Jungfraujoch, Atmos. Chem. Phys., 9, 3491-3503, doi:10.5194/acp-9-3491-2009, 2009. 